\title{
Totally robotic sleeve gastrectomy as a training model for residents and fellows
}

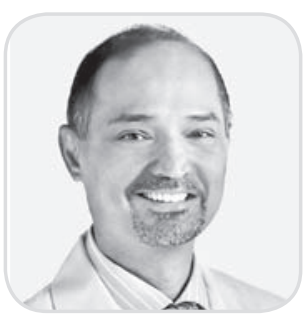

Chandra Hassan MD, FACS, Yevhen Pavelko MD, Stephan Gruessner MD, Valentina Valle MD, Antonio Gangemi MD, FACS, Francesco Bianco MD, FACS, Pier Giulianotti MD, FACS

UI Health-Division of General, Minimally Invasive \& Robotic Surgery, Department of Surgery, University of Illinois at Chicago, 820 South Wood Street, Rm 609, Clinical Sciences North Chicago, Chicago, IL, 60612, USA

\section{INTRODUCTION}

The utilization of robotic surgery has exponentially increased over the past decade [1]. The robotic platform overcomes limitations that are associated with laparoscopic surgery [2]. The technological innovations of the robotic platform help improve surgeon ergonomics and the surgical outcomes; such as, but not limited to, reduced blood loss and length of hospital stay [3].

Standardized training in robotic surgery has become necessary due to the increased demand which has led to the development of different robotic surgery curricula. There are curricula that offer basic training through online self-paced portals, such as the da Vinci Technology Training Pathway and Fundamentals of Robotic Surgery (FRS). On the other hand, the Fundamental Skills of Robot-Assisted Surgery (FSRS) training programs and the Robotics Training Network offer a more sophisticated form of hands-on training [1]. The use of the robotic technology in general surgery has expanded to numerous subspecialties, along with an increased exposure to surgical residents and development of fellowship programs that are focused on robotic assisted procedures [4].

Since its original establishment in the 1950's, bariatric surgery has emerged as a successful modality in the treatment of morbid obesity. Bariatric surgery became more popular due to better outcomes on weight loss, hyperglycemia control, hyperlipidemia, hypertension, cardiovascular risk, and mortality compared to medical therapy $[5,6]$. The two commonly performed procedures are laparoscopic sleeve gastrectomy (LSG) and laparoscopic Roux-en-Y-gastric bypass (RYGB) [7]. Bariatric surgery is technically complex and requires a superb understanding of anatomical landmarks and key steps of the procedures to prevent morbidity and mortality. There have been numerous studies involving residents and fellows showing variable results with most of them being negative. The affects seen are primarily based on prolonged operative duration [8].

With newer DaVinci Xi model and vessel sealer, sureform stapler, the comprehensive learning of individual steps of surgery is seamless for the residents. Utilization of laparoscopic technique remains challenging in morbidly obese patients due to the rigidity of instruments and poor ergonomics. Robotic surgery has become an alternative approach which often provides a shorter learning curve compared to laparoscopy, due to improved dexterity, precision, and $3-D$ visualization [9].

There are studies comparing laparoscopic and robotic vertical sleevegastrectomy (RVSG) that have demonstrated comparable outcomes between the two approaches. RVSG demonstrates a shorter learning curve compared to laparoscopy in approximately 20 cases $[8,10]$.

Yevhen Pavelko, MD, Clinical Research Specialist, Fellow Department of Surgery UI Health — Division of General, Minimally Invasive \& Robotic Surgery University of Illinois at Chicago. 820 South Wood Street, Rm 609, Clinical Sciences North, Chicago, IL 60612. Office: (312) 413-0886, Cell: (847) 714 -6680. E-mail: ypavelko@uic.edu. Phone: +1 847-714-6680 
We hypothesize that RVSG is a good training model for residents and fellows. Additional advantages of the robotic platform may benefit trainees when introducing them to any of the upper gastro-intestinal $(\mathrm{Gl})$ tract robotic cases.

\section{MATERIAL AND METHODS}

The basic retrospective analysis of all surgeries consisted of 20 randomly selected patients who underwent RVSG. All surgeries involved post-graduate year (PGY 2-5) residents and 1 fellow. All surgeries were done using the da Vinci $\mathrm{Xi}^{\mathrm{TM}}$ robotic system. A total of 16 PGY 4-5 level residents and one minimally invasive and robotic surgery fellow were working as the console surgeon under the guidance of an attending surgeon at the bedside. A total of 3 residents of PGY 2-3 were working as a console surgeon on certain steps of the procedure, as well as a bedside assistant when the attending surgeon took control on critical steps of the surgery. All cases were done using our standard technique. A total of 4 trocars were placed through $5 \mathrm{~mm}$ incisions in the epigastric area and the Iron Intern liver retractor was inserted to retract the left liver lobe. We started mobilization of the stomach by opening the gastrocolic ligament. Superior ergonomics and instrument stability of the robot allowed precise division of the short gastric arteries and gastro-splenic ligament. After full mobilization of the stomach, using a robotic stapler, sleeve gastrectomy performed.

Baseline pre-operative data collected included patient demographics, weight, body mass index (BMI), comorbidities, and American Society of Anesthesiology (ASA) scores. Basic perioperative outcomes such as estimated blood loss (EBL), operative time (OT), length of hospital stays (LOS), and 30-day readmission rates were collected, as well. A more extended analysis on outcomes comparing robotic vs laparoscopic vertical sleeve gastrectomy and Roux-en-Y gastric bypass, adjusted to residents PGY levels will follow this study. The future report will include a larger cohort of patients.

\section{RESULTS}

The study sample included 20 total patients who underwent robotic vertical sleeve gastrectomy. Most patients were female (75\%) vs (25\%) male. The summary characteristic and comorbidities of the patients who underwent laparoscopic vs fully robotic sleeve gastrectomy are listed in Table.

According to the patient preoperative data, the mean age of the patients was $37.0 \pm 13.8$ years. The mean

\begin{tabular}{|l|l|}
\hline $\begin{array}{l}\text { Patients' characteristics, comorbidities, } \\
\text { and other factors }\end{array}$ & RVSG (N=20) \\
\hline Age, year (Mean \pm SD) & $37.0 \pm 12.0$ \\
\hline Male & $5(25 \%)$ \\
\hline BMI, kg/m² (Mean \pm SD) & $51.0 \pm 10.0$ \\
\hline Hypertension & $8(40 \%)$ \\
\hline Hyperlipidemia & $3(15 \%)$ \\
\hline Smoking & $1(5 \%)$ \\
\hline Gastroesophageal reflux disease & $0(0 \%)$ \\
\hline COPD & $2(10 \%)$ \\
\hline Diabetes mellitus & $6(30 \%)$ \\
\hline Dialysis & $1(5 \%)$ \\
\hline Chronic steroid use & $0(0 \%)$ \\
\hline Renal insufficiency & $1(5 \%)$ \\
\hline Obstructive sleep apnea & $2(10 \%)$ \\
\hline Mean operative duration (Minutes \pm SD) & $121.1 \pm 30.0$ \\
\hline Mean length of stay (Days \pm SD) & $1.05 \pm 0.37$ \\
\hline
\end{tabular}

weight was $136.7 \pm 38.24 \mathrm{~kg}$, and mean BMl was $51.0 \pm$ $10.15 \mathrm{~kg} / \mathrm{m} 2$. With regards to preoperative comorbidities, the diabetes rate was $30 \%$ (6), chronic obstructive pulmonary disease was in $10 \%$ (2), and hypertension was in $40 \%$ (8). The mean ASA class was 2.4 .

During RVSG, 4 cases had concurrent additional procedures performed: 1 patient with a slipped gastric band removal and revision to vertical sleeve gastrectomy, 1 patient status, post-liver/kidney donation, underwent a re-do of sleeve gastrectomy, 1 patient, post-kidney transplant, underwent extensive adhesiolysis for one hour, and 1 patient had a hiatal hernia repair with vertical sleeve gastrectomy. The average time of 4 cases were additional procedures were done was $154.5 \pm 28.95 \mathrm{~min}$; (Min-Max $=125-191 \mathrm{~min})$. The mean OT was $121.1 \pm$ $30.33 \mathrm{~min}$. The mean EBL was $5.5 \pm 1.5 \mathrm{ml}$ and no patients required blood transfusion. The mean length of hospital stay was $1.05 \pm 0.39$ days.

A regression analysis showed that patient BMI, weight, and age did not correlate with the operative time of the sample population $(p=0.92,0.48$, and 0.30 respectively). All patients had an uneventful intraoperative and post-operative course. Two patients were readmitted for nausea and vomiting observation. No leaks, significant morbidity or mortality occurred.

\section{DISCUSSION}

Robotic surgery is a rapidly expanding field of General Surgery with an increase in the number of 
available programs training residents in robotic platform.

It is very important to balance patient safety, as well as training for the next generation of surgeons [11]. A recent study, based on a survey of contemporary surgical residents, has shown that majority of residents have been exposed to robotic cases, but fewer than $10 \%$ had a chance to operate as a console surgeon [12].

In our study, we are reporting that residents of the PGY level $4-5$ were working as a primary surgeon, when they performed critical steps of the procedure under the guidance of the attending surgeon. A PGY level $2-3$ residents were able to do a greater curvature mobilization up to the level of gastro-splenic ligament, using a da Vinci Xi vessel sealer and then continue as a bedside assistant.

There were no intraoperative complications such as major bleeding or spleen trauma in all cases. The residents were able to recognize important landmarks and structures thanks to superior visualization and stability of the robotic platform. During mobilization of posterior fundus of the stomach, residents were able to identify the left crus and proper surgical plane and avoid any inadvertent pancreatic injury. We hypothesize that the superior visualization, stability of the platform, and endo-wristed instruments of the robotic platform may benefit trainees in navigating the anatomy of the upper GI tract in three dimension and foregut surgeries.

Another possible benefit of robotics is its ergonomics in super morbidly obese patients that allows precise dissection in difficult-to-access operative fields. The robot has shown possible advantages over laparoscopy for patients with $\mathrm{BMI} \geq 50 \mathrm{~kg} / \mathrm{m}^{2}$ in certain bariatric procedures [13] and the mean BMI was $51.0 \pm 10.15 \mathrm{~kg} / \mathrm{m}^{2}$ in our cohort of patients. While a patient with a large BMI would normally hinder and prolong the operation, we were unable to show a correlation between the operative time and $\mathrm{BMI} /$ weight of the patients $(p=0.92$ and 0.48 respectively). A larger cohort of patients is needed to increase statistical power to be able prove the correlation between operative time and BMI.

In our study, we have found that the mean operative time was longer $(121.1 \pm 30.33 \mathrm{~min})$, but still comparable to other reported studies that do not report the involvement of trainees $(102 \pm 43 \mathrm{~min}-116.3 \pm 24.7)$ $[14,15]$. The Ecker at al. study reports that majority of patients' BMI did not exceed $50 \mathrm{~kg} / \mathrm{m}^{2}$ [9]. Additional factors of increased mean operative time might be concurrent to additional procedures that were performed along with RSG, some of which were technically challenging. However, at the same time trainees, had additional exposure to a number of procedures that alone can be difficult to perform.

The RVSG can be an excellent teaching model for any robotic upper Gl surgery as it provides good understanding of anatomical landmarks, important structures, and surgical planes for general surgery residents and fellows. This can prepare any trainee to understand the anatomy of the stomach and its topographic relationship to other organs. Trainees will also be able to recognize critical structures such as the pancreas, splenic vessels, left crus of the diaphragm, vagus nerve, etc.

\section{CONCLUSIONS}

Superior visualization and instrumental dexterity of the robotic platform is an excellent teaching tool for residents and fellows, even in complex cases involving morbidly obese patients. A critical step of sleeve gastrectomy is proper mobilization of posterior fundus and the identification of the left crus. In patients with BMI 50, it can be a challenging task laparoscopically. A robotic approach facilitates the visualization and mobilization of the posterior fundus, which can be achieved by trainees without a higher risk of bleeding and splenic trauma.

\section{Ethics declarations.}

Conflict of Interest. The authors declare that they have no conflict of interest.

Informed Consent. For this type of study, formal consent is not required. Informed consent was obtained from all individual participants included in the study.

\section{REFERENCES}

1. Chen $R$ et al. A comprehensive review of robotic surgery curriculum and training for residents, fellows, and postgraduate surgical education. Surg Endosc.2020;34(1):361-7.

2. Giulianotti PC. et al. Robotics in general surgery: personal experience in a large community hospital. Arch Surg. 2003;138(7):777-84.

3. Peters BS. et al. Review of emerging surgical robotic technology. Surg Endosc. 2018;32(4):1636-55.

4. Mostaedi R. et al. Bariatric surgery and the changing current scope of general surgery practice: implications for general surgery residency training. JAMA Surg. 2015;150(2):144-51. 
5. Meek CL. et al. The effect of bariatric surgery on gastrointestinal and pancreatic peptide hormones. Peptides. 2016;77:28-37.

6. Piche ME. et al. Bariatric surgery-induced lower angiopoietin-like 2 protein is associated with improved cardiometabolic profile. Can J Cardiol. 2017;33(8): 1044-51.

7. Spaniolas K. et al. The changing bariatric surgery landscape in the USA. Obes Surg. 2015;25(8):1544-6.

8. Goldberg I, et al. Surgical trainee impact on bariatric surgery safety. Surg Endosc. 2019;33(9):3014-25.

9. Ecker BL. et al., Resident education in robotic-assisted vertical sleeve gastrectomy: outcomes and cost-analysis of 411 consecutive cases. Surg Obes Relat Dis. 2016;12(2):313-20.

10. Vilallonga R. et al. The initial learning curve for robotassisted sleeve gastrectomy: a surgeon's experience while introducing the robotic technology in a Bariatric Surgery Department. Minim Invasive Surg. 2012;2012:347131.

11. Kohn GP. et al. High case volumes and surgical fellowships are associated with improved outcomes for bariatric surgery patients: a justification of current credentialing initiatives for practice and training. J Am Coll Surg. 2010;210(6):909-18.

12. Farivar BS, Flannagan M, Leitman IM. General surgery residents' perception of robot-assisted procedures during surgical training. J Surg Educ. 2015;72(2):235-42.

13. Edelson PK. et al. Robotic vs. conventional laparoscopic gastric banding: a comparison of 407 cases. Surg Endosc. 2011;25(5):1402-8.

14. Fazl Alizadeh R. et al. Robotic versus laparoscopic sleeve gastrectomy: a MBSAQIP analysis. Surg Endosc. 2019;33(3):917-22.

15. Bhatia P. et al. Robot-assisted sleeve gastrectomy in morbidly obese versus super obese patients. JSLS. 2014;18(3).

SUMMARY
Totally Robotic Sleeve Gastrectomy
as a TrainingModel for Residents and Fellows
Chandra Hassan MD, FACS, YevhenPavelko MD,
Stephan Gruessner MD, Valentina Valle MD,
Antonio Gangemi MD, FACS, Francesco Bianco
MD, FACS, Pier Giulianotti MD, FACS

UI Health-Division of General, Minimally Invasive \& Robotic Surgery, Department of Surgery, University of Illinois at Chicago, 820 South Wood Street, Rm 609, Clinical Sciences North Chicago, Chicago, IL, 60612, USA

Introduction. The utilization of robotic surgery has exponentially increased over the past decade. The robotic platform overcomes limitations that are associated with laparoscopic surgery. The technological innovations of the robotic platform help improve surgeon ergonomics and the surgical outcomes; such as, but not limited to, reduced blood loss and length of hospital stay.

There are studies comparing laparoscopic and robotic vertical sleeve gastrectomy (RVSG) that have demonstrated comparable outcomes between the two approaches. We hypothesize that RVSG is a good training model for residents and fellows.

Materials and methods. The basic retrospective analysis of all surgeries consisted of 20 randomly selected patients who underwent RVSG.All surgeries were done using the da Vinci $\mathrm{Xi}^{\mathrm{TM}}$ robotic system. A total of 16 PGY $4-5$ level residents and one minimally invasive and robotic surgery fellow were working as the console surgeon under the guidance of an attending surgeon at the bedside.

Results and discussion. The study sample included 20 total patients who underwentRVSG. The average time of 4 cases where additional procedures were done was $154.50 \pm 28.95 \mathrm{~min}$; (Min-Max = 125-191 min). The mean operative time was $121.10 \pm 30.33 \mathrm{~min}$. The mean estimated blood loss was $5.5 \pm 1.5 \mathrm{ml}$ and no patients required blood transfusion. The mean length of hospital stay was $1.05 \pm 0.39$ days. A regression analysis showed that patient body mass index, weight, and age did not correlate with the operative time of the sample population $(p=0.92,0.48$, and 0.30 respectively). All patients had an uneventful intraoperative and postoperative course.

Conclusions. Superior visualization and instrumental dexterity of the robotic platform is an excellent teaching tool for residents and fellows, even in complex cases involving morbidly obese patients. In patients with body mass index $>50$, it can be a challenging task laparoscopically. A robotic approach facilitates the visualization and mobilization of the posterior fundus, which can be achieved by trainees without a higher risk of bleeding and splenic trauma.

Keywords: totally robotic sleeve gastrectomy, training model, residents, fellows

\section{PEЗЮME}

\section{Повністю роботизована рукавна гастректомія як навчальна модель для аспірантів і співробітників}

Chandra Hassan MD, FACS, Yevhen Pavelko MD, Stephan Gruessner MD, Valentina Valle MD, Antonio Gangemi MD, FACS, Francesco Bianco MD, FACS, Pier Giulianotti MD, FACS 
UI Health-Division of General, Minimally Invasive \& Robotic Surgery, Department of Surgery, University of Illinois at Chicago, 820 South Wood Street, Rm 609, Clinical Sciences North Chicago, Chicago, IL, 60612, USA

Вступ. За останні 10 років значно частіше використовували роботизовану хірургію. Роботизована платформа позбавлена обмежень, пов'язаних 3 лапароскопічною хірургією. Технологічні нововведення роботизованої платформи допомагають поліпшити ергономіку хірурга та результати хірургічного втручання, зокрема зменшити об'єм крововтрати і тривалість перебування пацієнта в лікарні.

Існують дослідження із порівняння лапароскопічної та роботизованої вертикальної рукавної гастректомії (РВРГ), які продемонстрували порівнянні результати цих двох методів. На нашу думку, РВРГ $\epsilon$ гарною моделлю для навчання аспірантів і співробітників клініки.

Матеріали та методи. Проведено ретроспективний аналіз даних щодо операцій у 20 випадково відібраних пацієнтів, яким виконали РВРГ за допомогою роботизованої системи daVinciXi ${ }^{\mathrm{T}}$. В усіх операціях взяли участь 16 аспірантів та 1 малоінвазивний та робототехнічний хірург під керівництвом лікуючого хірурга.

Результати. У досліджувану вибірку включили 20 пацієнтів, яким була проведена РВРГ.Середній час виконання чотирьох додаткових процедур становив $(154,50 \pm 28,95)$ хв (від 125 до 191 хв). Середня тривалість операції - $(121,10 \pm 30,33)$ хв. Середній об'єм крововтрати - $(5,5 \pm 1,5)$ мл. Жоден пацієнт не потребував переливання крові. Середня тривалість перебування в лікарні становила $(1,05 \pm 0,39)$ дня. Регресійний аналіз виявив, що індекс маси тіла, маса тіла і вік пацієнта не корелювали з тривалістю операції ( $p=0,92,0,48$ та 0,30 відповідно). Не спостерігалося жодних ускладнень в інтра- та післяопераційному періодах.

Висновки. Відмінна візуалізація та відповідні інструменти роботизованої платформи роблять її хорошим навчальним інструментом для аспірантів і співробітників навіть у складних випадках у пацієнтів з ожирінням. У пацієнтів з індексом маси тіла > 50 кг/м² складно виконувати лапароскопічні операції. Роботизований підхід полегшує візуалізацію та мобілізацію шлунка без підвищеного ризику кровотечі та травми селезінки.

Ключові слова: повністю роботизована рукавна гастректомія, навчальна модель, співробітники, аспіранти.

\section{PEЗЮME \\ Полностью роботизированная рукавная гастрэктомия как учебная модель для аспирантов и сотрудников}

Chandra Hassan MD, FACS, Yevhen Pavelko MD, Stephan Gruessner MD, Valentina Valle MD, Antonio Gangemi MD, FACS, Francesco Bianco MD, FACS, Pier Giulianotti MD, FACS

UI Health-Division of General, Minimally Invasive \& Robotic Surgery, Department of Surgery, University of Illinois at Chicago, 820 South Wood Street, Rm 609, Clinical Sciences North Chicago, Chicago, IL, 60612, USA

Введение. За последние 10 лет значительно чаще используется роботизированная хирургия. Роботизированная платформа лишена ограничений, связанных с лапароскопической хирургией. Технологические нововведения роботизированной платформы помогают улучшить эргономику хирурга и результаты хирургического вмешательства, в частности уменьшить объем кровопотери и продолжительность пребывания пациента в больнице.

Существуют исследования по сравнению лапароскопической и роботизированной вертикальной рукавной гастрэктомии (РВРГ), которые продемонстрировали сравнимые результаты этих двух методов. По нашему мнению, РВРГ является хорошей моделью для обучения аспирантов и сотрудников клиники.

Материалы и методы. Проведен ретроспективный анализ данных операций 20 случайно отобранных пациентов, которым выполнили РВРГ с помощью роботизированной системы daVinciXi ${ }^{\text {тм}}$. Во всех операциях приняли участие 16 аспирантов и 1 малоинвазивный и робототехнический хирург под руководством лечащего хирурга.

Результаты. В исследуемую выборку включили 20 пациентов, которым была проведена РВРГ. Среднее время выполнения четырех дополнительных процедур составляло $(154,50 \pm 28,95)$ мин (от 125 до 191 мин). Средняя продолжительность операции - $(121,10 \pm 30,33)$ мин. Средний объем кровопотери - $(5,5 \pm 1,5)$ мл. Ни один пациент не нуждался в переливании крови. Средняя продолжительность пребывания в больнице составила (1,05 \pm $0,39)$ дня. Регрессионный анализ выявил, что индекс массы тела, масса тела и возраст пациента не коррелировали с продолжительностью операции ( $\mathrm{p}=$ 0,92, 0,48 и 0,30 соответственно). Каких-либо ослож- 
нений в интра- и послеоперационном периодах не наблюдалось.

Выводы. Отличная визуализация и соответствующие инструменты роботизированной платформы делают ее хорошим учебным инструментом для аспирантов и сотрудников даже в сложных случаях у пациентов с ожирением. У пациентов с индексом массы тела > 50 кг/м² сложно выполнять лапароскопические операции. Роботизированный подход облегчает визуализацию и мобилизацию желудка без повышенного риска кровотечения и травмы селезенки.

Ключевые слова: полностью роботизированная рукавная гастрэктомия, учебная модель, сотрудники, аспиранты.

Дата надходження до редакції 02.10.2020 p. 